\title{
The Marketing Strategy for Cruise Home Port in Andaman Tourism Cluster in Thailand
}

\author{
Anothai Ngamvichaikit, Achara Cheevatragoonkit, Sritana Boonyasait, Suradetch Wangthong, and \\ Gunyanuch Kittipongpittaya
}

\begin{abstract}
Cruise Tourism is growing dramatically especially in Asia. Thailand posits as the best tourist destination with cruise port of call and considers to set up Andaman home port recently. Hence, the marketing strategy is demanded for revenue compensated port cost. This research aimed to develop the marketing strategy for cruise home port in Andaman Tourism Cluster of Thailand. The methodology used six step qualitative approach with relevant stakeholders of cruise tourism and port in Thailand. The SWOT analysis was conducted and evaluated by analytic hierarchy process. The TOWS matrix was employed and suggested the 3 key marketing strategy; 1) Product Development Strategy, 2) Market Development Strategy and 3) Business Network Development Strategy. The detailed findings were validated with the panel of 10 experts and Andaman tourism association representatives. Further implication for recommended marketing strategy can be utilized for tourism policy in Thailand.
\end{abstract}

Index Terms-Marketing strategy, cruise port, Andaman tourism cluster, Thailand.

\section{INTRODUCTION}

The Cruise Tourism grows especially in the era of increasing aged population. According to research by the Cruise Lines International Association [1], Asia is a fast-growing cruise market, and $80 \%$ of cruise liners are confident to expand into this region. With the Asian optimistic growth, the ports in the region are encouraged to expand and establish as home port including Andaman tourism ports [2]. Although the economic contribution from cruise tourism is potentially significant to the nation, the investment upon port infrastructure remains huge amount and country needs to find marketing strategy to attract cruise lines and passengers to spend their trip. The home port policy should focus to increase competitiveness in terms of associated tourism infrastructure [3].

The Andaman tourism cluster of Thailand, focused in this study, located on Thailand west sea border, including Ranong, Phang Nga, Phuket, Krabi, Trang and Satun province. The so called pearl of Andaman, Phuket catered millions of tourists and generate numerable income to Thailand [4]. Despite the limited port capacity in Andaman, more cruise tourists visit Andaman port for sea, sand and sun increasingly every year [5]. The potential port infrastructure in Phuket is now considered to upgrade toward home port recently.

Manuscript received July 27, 2017; revised September 6, 2018. This work was supported in part by the Thailand Research Fund (TRF) under Grant.

Anothai Ngamvichaikit is with the Sukhothai Thammathirat Open University, Nonthaburi, Thailand (e-mail: anothai.ne@gmail.com).
This research proposes marketing strategy for the cruise home port of Andaman tourism cluster in Thailand. The paper is structured in 5 sections starting from introduction as Section I, a literature review in next Section II, a research methodology in Section III, result in Section IV and finally conclusion and discussion in Section V.

\section{LITERATURE REVIEW}

The literature review consists of 3 topics related with marketing strategy development of cruise home port in Andaman, Thailand; Current Andaman Cruise Tourism, Marketing Strategy and Research in cruise tourism.

\section{A. Current Andaman Cruise Tourism}

Cruise tourist in Andaman currently came from Asia. Current ports in Andaman remain port of call in Phuket and Krabi. Hence the travel connectivity to other international airport in Phuket is better.

Cruise tourists'spending of 188 USD [6] compared with normal tourists'spending of 130 USD [7], the cruise tourists contribute economically more than general tourists. With Andaman port of call, current travel time duration at Andaman is limited within 12 hours for port of call. Whereas if Phuket is home port, the duration of Thailand travel can increase for pre and post-trip and port stay with longer period as shown in Fig. 1.

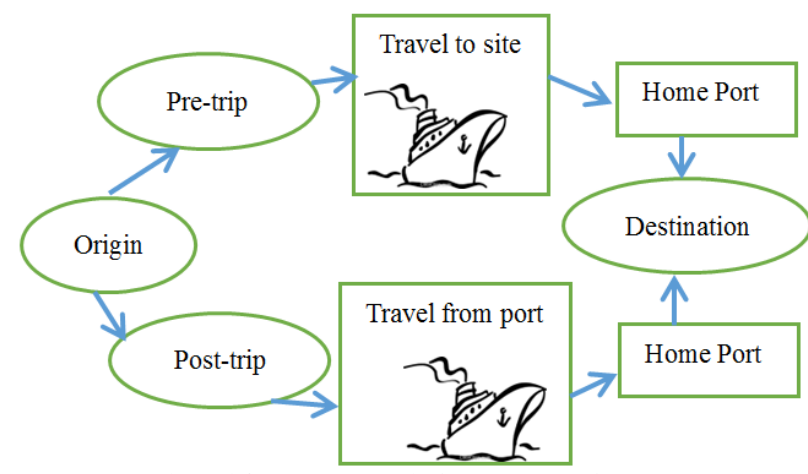

Source: Adapted from Wang and Pizam (2011, Fig.7.1 p.101) [8] Fig. 1. Travel process for cruise tourism.

Multimodal transportation management requires high skill of planning. Logistics professionals who handle multimodal delivery can approach to integrate in operation, management and control of transportation, so that delivery from origin to destination is possibly shorter.

\section{B. Marketing Strategy}

Marketing strategy started from situation analysis with SWOT. SWOT analysis derived their S-W-O-T from the 
assessment of internal situation including Strengths (S) and Weaknesses (W) as well as external situation including Opportunities (O), and Threats (T) [9] underlined for the key success factor. Company can generate key strategy from consider SWOT components rigorously. However, the subjective evaluation possesses a major improvement: the need for the importance ranking for each SWOT factors. The developed analysis of SWOT incorporates Analytic Hierarchy Process (AHP) to prioritize each component of SWOT [10]-[12].

To create key strategy from SWOT, pairing key internal and external factors become challenging procedure of generating a TOWS matrix [13] as shown in Fig. 2 with following:

SO (strengths and opportunities) strategies use an organizational internal strengths to leverage external opportunities.

WO (weaknesses and opportunities) strategies improve internal organizational weaknesses and leverage external opportunities.

ST (strengths and threats) strategies use organizational strengths to avoid or decrease the effect of external threats.

WT (weaknesses and threats) strategies as defensive strategies improve internal weaknesses and avoid environmental threats.

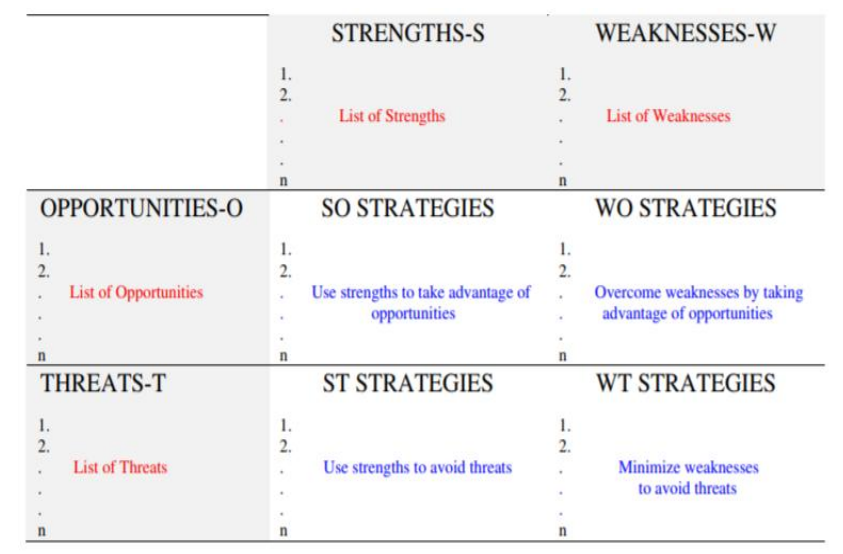

Source: Sevkli et al. (2012, Fig. 1, p. 15)

Fig. 2. A presentation of TOWS matrix.

\section{Research in Cruise Tourism}

The destination attributes like safety, transportation and price effect on tourist satisfaction. Cruise visitor satisfaction with a destination remains important consumer indicator for cruise port, the research found that satisfaction delineates to cruise tourist revisit and world of mouth [14]. The information provision and logistic connection are recommended to set up in cruise home port. The cruise port is assessed their value regarding to provincial value like culture, history and aesthetic places [15].

The community related with cruise port needs to be well-informed because they share their environment with cruise travel. The resident stress could be occurred if the cruise port had been established [16].

\section{RESEARCH Methodology}

The research methodology used qualitative approach with
AHP to prioritize the factors [2], [12], [17]. The method consists mainly of six steps as shown in Fig. 2. In the first step, researchers gather the data of current situation from two sources: one is thorough research with government and business documents and the another is the primary source from in-depth-interview series the 12 relevant stakeholders which include government executives, cruise tourism entrepreneurs and related association deputy. Next step, both external and internal situation factors were formulated from content analysis. In the third step, a detailed SWOT analysis was performed based on research questions. Fourth, the results of SWOT were sent to 5 experts to rank based on pairwise comparison. For the five step, the TOWS matrix was conducted and generated the detail strategy. The categorization into 3 category were performed. Lastly, the presentations with 2 focus groups in Phuket and Bangkok were arranged to validate the findings. Total duration of qualitative research was 6 months from December, 2016 to May, 2017.

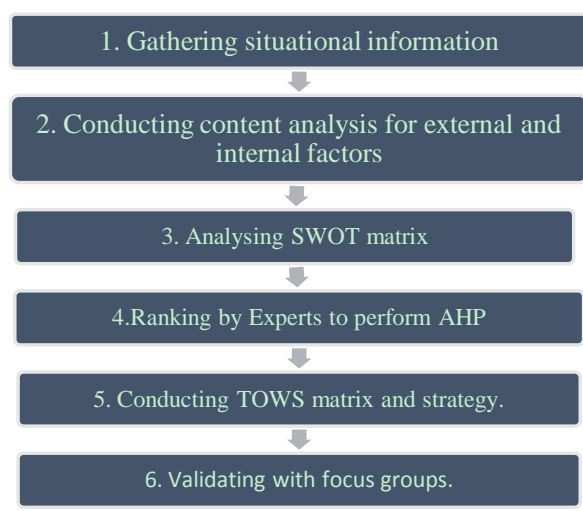

Fig. 3. Six steps in this research.

TABLE I: SWOT MATRIX RANKED FROM THE PERCENTAGE OF IMPORTANCE SCORE.

\begin{tabular}{|c|c|}
\hline Factors & Situation \\
\hline $\begin{array}{l}\text { Political } \\
\text { Factor }\end{array}$ & $\begin{array}{l}\text { - Thailand poses stabilized political climate in } \\
\text { tourist percpetion }\end{array}$ \\
\hline $\begin{array}{l}\text { Economic } \\
\text { Factor }\end{array}$ & $\begin{array}{l}\text { - Tourism become mainstay of Thailand economy } \\
\text { especially Andaman tourism. } \\
\text { - The Thailand location provide geographical } \\
\text { advantage to offer exotic travel route and } \\
\text { destination within CLMV region. }\end{array}$ \\
\hline $\begin{array}{l}\text { Socio-cultural } \\
\text { Factor }\end{array}$ & $\begin{array}{l}\text { - Higher elderly population effects on the increasing } \\
\text { travel by cruise. } \\
\text { - More global environmental concern establishs } \\
\text { ecology tourism and effects on Andaman tourism } \\
\text { management. }\end{array}$ \\
\hline $\begin{array}{l}\text { Technology } \\
\text { Factor }\end{array}$ & $\begin{array}{l}\text { - Internet penetration in Andaman is acceptable but } \\
\text { the information technology is needed to improve } \\
\text { for cost effectiveness in tourism management. }\end{array}$ \\
\hline $\begin{array}{l}\text { Cruise } \\
\text { operator } \\
\text { behavior }\end{array}$ & $\begin{array}{l}\text { - The service operation adapts to various groups of } \\
\text { customers with various size of cruises and route of } \\
\text { travel. } \\
\text { - They target toward mid income passengers } \\
\text { especially in Asia. } \\
\text { - The competition drives for marketing promotions } \\
\text { to retain cruise tourists. }\end{array}$ \\
\hline $\begin{array}{l}\text { Cruise tourist } \\
\text { behavior }\end{array}$ & $\begin{array}{l}\text { - Asia cruise tourists increase with younger, family } \\
\text { bounded and shorter duration. } \\
\text { - The website becomes new source of information } \\
\text { to perform cruise decision. } \\
\text { - Asia tourists expect the offering of new route and } \\
\text { price promotion whereas Europe and US cruise } \\
\text { tourists expect on service process operation and } \\
\text { people quality. }\end{array}$ \\
\hline
\end{tabular}




\section{RESULTS}

The situational analysis found the critical factors as shown in Table I.

The SWOT matrix was developed and compared between each pair of components by 5 cruise tourism experts. The importance percentage were derived from AHP pairwise analysis [17] and specified in Table II.

TABLE II: SWOT MATRIX RANKED FROM THE PERCENTAGE OF IMPORTANCE SCORE.

\begin{tabular}{|l|l|}
\hline \multicolumn{1}{|c|}{ Strength (30) } & \multicolumn{1}{c|}{ Opportunity (13) } \\
\hline centralized among CLMV & O1 -Expansive cruise tourism with \\
regions. (54) & upsized cruise and Asia coverage. \\
S2 - Attractive destination (46) & O2 -Increasing Asia cruise tourists \\
& with higher spending. (27) \\
& O3 -Cruise tourist demand for new \\
& destination and route. (23) \\
& O4 -Higher spending power in \\
& cruise tourism. (11) \\
& O5 -Stable and Safe Thailand \\
& destination in tourism. (11) \\
\hline \multicolumn{1}{|c|}{ Weakness (23) } & Threat (34) \\
\hline W1- Inefficient public & T1- Lack of government policy \\
transportation, logistics & integration to develop Andaman \\
infrastructure and utility. (57) & tourism cluster. (66) \\
W2- Insufficient capacity in & T2- Increasing cruise competition \\
Andaman Tourism sites. (29) & within Southeast Asia region. (28) \\
W3-Quality problem of & T3- Low connectivity of \\
Tourism professionals to serve & International airlines with \\
multiple language tourists. (14) & Andaman airport (6) \\
\hline
\end{tabular}

TOWS matrix was developed from matching internal and external factors to identify initial strategies for cruise home port as Table III.

TABLE III: TOWS MATRIX TO DEFINE INITIAL STRATEGIES.

\begin{tabular}{|c|c|}
\hline S-O Strategy & S-T Strategy \\
\hline $\begin{array}{l}\text { - Offer the cruise route to increase } \\
\text { travel duration and spending in } \\
\text { Thailand. (S2-O12345) } \\
\text { - Present the connected route from } \\
\text { Andaman port to Myanmar and } \\
\text { neighboring countries. } \\
\text { (S1-O12345) }\end{array}$ & $\begin{array}{l}\text { - Develop the tourist places in } \\
\text { Andaman with community and } \\
\text { government } \\
\text { organization.(S1-T1) } \\
\text { - Cooperate with airlines to } \\
\text { create fly-cruise program to } \\
\text { cruise home port. (S2-T3) }\end{array}$ \\
\hline W-O Strategy & W-T Strategy \\
\hline $\begin{array}{l}\text { Develop public transportation, } \\
\text { facility, utility and logistics } \\
\text { infrastructure. (W1-O12345) } \\
\text { Develop people service quality } \\
\text { with education and training. } \\
\text { (W2-O12345) }\end{array}$ & $\begin{array}{l}\text { - Target qualified tourists to } \\
\text { match with existing capacity of } \\
\text { public facility and tourist sites. } \\
\text { (W12-T13) } \\
\text { - Collaborate with neighboring } \\
\text { port as collaborative } \\
\text { competition to connect each } \\
\text { other. (W12-T2) }\end{array}$ \\
\hline
\end{tabular}

Initial strategies from TOWS matrix were categorized to 3 key strategies to propose for relevant stakeholders. First strategy, product development strategy aimed to create proper tourism product to serve with cruise tourists who need variety of travel programs ranged from adventure to healthcare to make family and repetitive trip. Second strategy, market development strategy purposed to expand qualified market for cruise tourism by promoting new routes with Phuket home port for cruise lines. The third strategy, business network development strategy focused on building travel business network by creates mutual understanding and improvement to higher service quality for cruise tourism. The key detailed strategies have been endorsed from expert focus groups as shown in Table IV.
TABLE IV: Key STRATEGIES FOR CRUISE HOME PORT IN ANDAMAN TOURISM CLUSTER

Strategy 1 Product Development Strategy

- Develop tourist sites including cultural heritage, adventure place, niche travel sites in Phuket and neighboring provinces.

- Create pre and post trip to support cruise trip starting from Phuket.

- Develop the connected route to Myanmar, Srilanka and India with Phuket cruise home port.

Strategy 2 Market Development Strategy

- Present developmental plan toward key stakeholders; cruise lines, connected port authority, and domestic business network.

- Promote the modernization of port and supportive infrastructure toward cruise lines and tourism authority in target source countries.

- Promote the new routes including Phuket and vicinity, connected port and new destination to Myanmar, Srilanka and India.

Strategy 3 Business Network Development Strategy

- Develop community tourism potential in Phuket and vicinity.

- Develop service quality of relevant service business to serve with cruise tourism.

- Collaborate with airlines to connect Phuket home port with target source countries.

\section{CONCLUSION AND DISCUSSION}

The cruise tourism industry become fascinating growing sector, which potentially contributes financial income to nations. Recently, Asia countries like China, Taiwan, Korea, Japan, Singapore, Malaysia actively recognize and develop their cruise ports to serve cruise industry. Andaman port of Thailand also posits as one of potential port to grow in Asia Cruise Trend, however the more revenue is demanded from establish a home port. This research proposed the marketing strategy for Andaman cruise home port which will set up at Phuket province. From six-step qualitative research, the three main strategies were proposed as shown in Fig. 4.

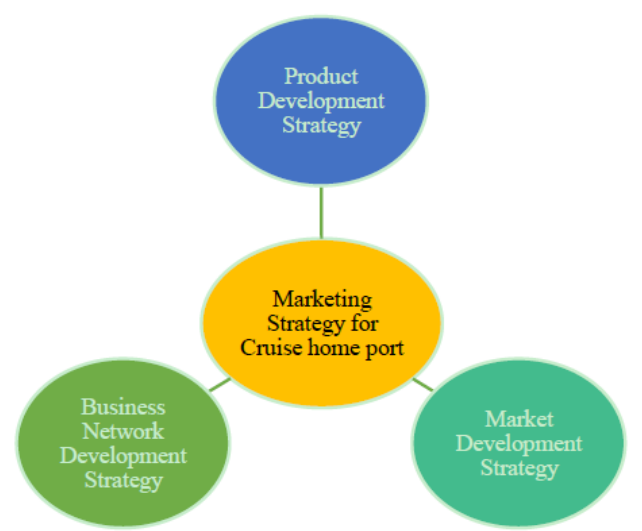

Fig. 4. Three key marketing strategies for for Cruise Home Port in Andaman Tourism Cluster in Thailand.

Tourism product development in Phuket and vicinity remains important factor for cruise tourist satisfaction and purchasing decision [14], [18]. To increase demand side of cruise tourism, the public presentation with cruise lines and target source markets is encouraging to conduct by cruise tourism taskforces who are set up from both government and private parties to expand market for Thailand cruise port [19]. From empirical research, Attracting qualified cruise tourists need premium providers with higher service quality and offering escape experience [20]. The holistic tourism business needs to understand clear cruise tourism behavior and develop their services together as a business network.

This research provides strategic implications and 
suggestions toward government, tourism authority and travel business stakeholders for the development of cruise home port to develop their product, market and network in order to attract more cruise lines and tourists. Finally the country economic contribution ensures ultimate result of sustainable investment.

\section{ACKNOWLEDGMENT}

This research is one section of national research project of Cruise Home Port Development in Andaman Tourism Cluster of Thailand which was fully supported by Thailand Research Fund. Researchers would like to thank for all participants in this study who contributed their time and effort.

\section{REFERENCES}

[1] CLIA. Asia Cruise Trends 2016 Report. [Online]. Available: https://docs.google.com/viewerng/viewer?url=https://cruising.org/doc s/default-source/research/clia-2016-asia-cruise-trends-report-.pdf?sfvr $\mathrm{sn} \% 3 \mathrm{D} 0$

[2] Y. Wang et al., "Selecting a cruise port of call location using the fuzzy-AHP method: A case study in East Asia," Tourism Management, vol. 42 , pp. 262-270, 2014

[3] J. McCarthy, "The cruise industry and port city regeneration: The case of Valletta," European Planning Studies, vol. 11, pp. 341-350, 2003.

[4] N. Kontogeorgopoulos, "Tourism in Thailand," The Routledge Handbook of Tourism in Asia, 2016.

[5] Phuket Immigration. Phuket Cruise Statistics. [Online]. Available: www.phuketimmigration.go.th.

[6] Business Research and Advisor. Economic Contribution of Cruise Tourism in Southeast Asia. [Online]. Available: http://www.cruising.org/docs/default-source/market-research/2014-so utheast-asia-economic-impact-study-nbsp---major-findings.pdf?sfvrsn $=0$

[7] Ministry of Tourism and Sports. (2015). Tourism Economic Review. [Online]. http://www.mots.go.th/ewt_dl_link.php?nid=8265

[8] Y. Wang and A. Pizam, Destination Marketing and Management: Theories and Applications, Cabi, 2011.

[9] K. R. Andrews, "The concept of corporate strategy," New York, 1971

[10] M. Sevkli et al., "Development of a fuzzy ANP based SWOT analysis for the airline industry in Turkey," Expert Systems with Applications, vol. 39, pp. 14-24, 2012.
[11] C. Kahraman et al., "Prioritization of e-Government strategies using a SWOT-AHP analysis: the case of Turkey," European Journal of Information Systems, vol. 16, pp. 284-298, 2007.

[12] P. Ajmera et al., "Prioritization of strengths, weaknsses, opportunities and threats of indian medical tourism sector using integrated SWOT AHP analysis," International Journal of Innovative Research in Science, Engineering and Technology, vol. 4, 2015.

[13] S. Kapoor and M. Kaur, "Basel III norms: A SWOT and TOWS approach," Vision, vol. 21, pp. 250-258, 2017.

[14] U. A. Ozturk and H. Gogtas, "Destination attributes, satisfaction, and the cruise visitor's intent to revisit and recommend," Tourism Geographies, vol. 18, pp. 194-212, 2016.

[15] G. Alkan et al., "Evaluation of Istanbul port in cruise tourism in terms of brand value," Management, vol. 4, pp. 276-285, 2015.

[16] E. J. Jordan et al., "A stress and coping framework for understanding resident responses to tourism development," Tourism Management, vol. 48, pp. 500-512, 2015

[17] T. L. Saaty, "The analytic hierarchy process, NY," Priority Ranking and Consensus Formation, Management Science, vol. 24, pp. 1721-1732, 1980.

[18] G. Yingzhi et al., "An empirical study on the correlation between cruising motivation and cruising intention," Journal of Tourism and Hospitality Management, vol. 2, pp. 114-123, 2014

[19] C.-A. Chen, "How can Taiwan create a niche in Asia's cruise tourism industry?” Tourism Management, vol. 55, pp. 173-183, 2016.

[20] B. Neuts et al., "Assessing customer value in segmented cruise markets: A modelling study on Japan and Taiwan," Academy of Marketing Studies Journal, vol. 20, pp. 1-13, 2016.

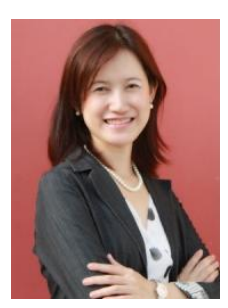

Anothai Ngamvichaikit was born in Bangkok on 27 August, 1973. She got the bachelor degree in pharmaceutical science from Chulalongkorn University, Bangkok, Thailand in 1999; master degree in marketing from Thammasart University, Bangkok, Thailand in 2003; PhD in management from Asian Institute of Technology, Pathumthani, Thailand in 2013.

She now works as a faculty member in management science faculty, Sukhothai Thammathirat Open University, Thailand. She experiences many years as a manager, lecturer and consultant in the pharmaceutical and health care service industry. Her papers has been published in International Journal of Pharmaceutical and Healthcare Marketing (High commended paper award), Managing Service Quality, Journal of Modern Management. Her research interest falls in the area of service marketing, SMEs, communication and healthcare organization management. 